\title{
Perbedaan Perilaku Kewargaan Organisasi berdasarkan Status Kerja Karyawan Hotel di Bali ditinjau dari Kualitas Kehidupan Kerja
}

\author{
Ni Wayan Sinthia Widiastuti dan Komang Rahayu Indrawati \\ Program Studi Psikologi, Fakultas Kedokteran, Universitas Udayana \\ komangrahayu@unud.ac.id
}

\begin{abstract}
Abstrak
Meningkatnya jumlah wisatawan yang datang ke Bali, menyebabkan sarana akomodasi, seperti hotel juga mengalami peningkatan. Adanya kebutuhan hotel akan sumber tenaga kerja serta melakukan efisiensi biaya sehingga manajemen hotel mempekerjakan karyawan dengan status kerja yang berbeda. Industri perhotelan merupakan salah satu sektor yang memerlukan perilaku kewargaan organisasi karena tujuan utama setiap hotel pada umumnya yaitu memberikan pelayanan yang terbaik dan berkualitas kepada wisatawan. Penelitian ini bertujuan untuk mengetahui perbedaan perilaku kewargaan organisasi berdasarkan status kerja karyawan hotel di Bali ditinjau dari kualitas kehidupan kerja. Sampel penelitian diambil secara acak dengan metode two-stage cluster sampling hingga mendapatkan 126 sampel dari 11 hotel di Denpasar. Subjek penelitian terdiri dari 64 karyawan dengan PKWTT (Perjanjian Kerja Waktu Tidak Tertentu) atau yang sering disebut dengan karyawan tetap dan 62 karyawan dengan PKWT (Perjanjian Kerja Waktu Tertentu) atau yang lebih dikenal dengan istilah karyawan kontrak, outsourcing, dan pekerja harian. Instrumen dalam penelitian ini adalah skala perilaku kewargaan organisasi dan skala kualitas kehidupan kerja. Hasil analisis ANCOVAmenunjukkan ada perbedaan perilaku kewargaan organisasi berdasarkan status kerja karyawan ditinjau dari kualitas kehidupan kerja. Perbedaan perilaku kewargaan organisasi dan kualitas kehidupan kerja ditinjau dari status kerja karyawan menggunakan analisis uji komparasi independent sample t-test yang menunjukkan ada perbedaan perilaku kewargaan organisasi dan kualitas kehidupan kerja antara karyawan dengan PKWTT dan karyawan dengan PKWT yang bekerja pada hotel di Bali. Hasil analisis regresi menunjukkan adanya hubungan fungsional antara kualitas kehidupan kerja dan perilaku kewargaanorganisasi.
\end{abstract}

Kata kunci: Perilaku Kewargaan Organisasi, Kualitas Kehidupan Kerja, Status Kerja Karyawan, Hotel di Bali

\begin{abstract}
The increasing number of tourists coming to Bali, causing accommodation facilities, such as hotels have increased. The existence of hotel needs will be the source of labor and cost efficiency so that hotel management employs employees with different working status. The hospitality industry is one of the sectors that require organizational citizenship behavior because the main goal of every hotel in general was to provide the best service and quality to tourists. The purpose of this study was to determine the differences in organizational citizenship behavior based on work status of employees at the Hotel in Bali in terms of quality of work life. Research sample was chosen randomly through twostage cluster sampling which succeed to obtain 126 samples from 11 hotels in Denpasar. The subjects consisted of 64 employees with PKWTT (Employment Agreement of Uncertain Time) or who is often called a permanent employee and 62 employees with PKWT (Employment Agreement of Certain Time) or better known as contract employees, outsourcing, and daily workers. Instruments in this study was the scale of organizational citizenship behavior and the scale of quality of work life. The results of ANCOVA analysis showed there were differences in organizational citizenship behavior based on employee work status in terms of quality of work life. Differences in organizational citizenship behavior and quality of work life based on work status of employees using comparative test was analysis by independent sample t-test shows there were differences in organizational citizenship behavior and quality of work life between employees with PKWTT and employees with PKWT working in hotels in Bali. The result of the regression analysis showed the functional relationship between quality of work life and organizational citizenshipbehavior.
\end{abstract}

Keywords: Organizational Citizenship Behavior, Quality of Work Life, Work Status of Employees, Hotel in Bali 


\section{LATAR BELAKANG}

Bali merupakan salah satu tujuan wisata di Indonesia. Keberagaman seni, budaya serta keindahan alam yang dimilki Bali merupakan daya tarik bagi wisatawan. Hal ini ditunjukkan dengan meningkatnya wisatawan yang berkunjung ke Bali. Berdasarkan Badan Pusat Statistik Provinsi Bali (2015), setiap tahunnya wisatawan yang berkunjung ke Bali mengalami peningkatkan, pada tahun 2013 jumlah wisatawan yang berkunjung adalah3.278.598 jiwa, sedangkan pada tahun 2014 jumlah wisatawan berkunjung adalah 3.766.638 jiwa, dan pada tahun 2015 jumlah wisatawan yang berkunjung adalah 4.001.835 jiwa. Seiring dengan peningkatan jumlah wisatawan yang datang ke Bali, penyediaan sarana dan prasarana penunjang wisatawan seperti akomodasi juga mengalami peningkatan. Akomodasi adalah tempat tinggal sementara bagi seseorang yang sedang mengadakan perjalanan secara pribadi atau kelompok untuk tujuan tertentu. Menurut Sihite (2003), hotel merupakan suatu bentuk akomodasi yang dikelola secara komersil, dan disediakan bagi setiap orang untuk memperoleh pelayanan dan penginapan dilengkapi dengan makanan dan minuman.

Hotel merupakan salah satu akomodasi yang mengalami peningkatan di Bali. Berdasarkan data dari Badan Pusat Statistik Provinsi Bali (2015), pada tahun 2010 jumlah hotel di Bali adalah 2.190, sedangkan pada tahun 2014 jumlah hotel di Bali mencapai3.039. Berdasarkan Peraturan Menteri Pariwisata dan Ekonomi Kreatif Nomor Pm.53/Hm.001/Mpek/2013, terdapat penggolongan kelas hotel yang terdiri atas, hotel bintang satu, hotel bintang dua, hotel bintang tiga, hotel bintang empat, hotel bintang lima. Kriteria penggolongan tersebut didasarkan pada persyaratan dasar dan penilaian teknis operasional. Tingkat penghunian kamar (TPK) tertinggi pada hotel di Bali tahun 2015 dimiliki oleh hotel bintang lima sebanyak 73,56\% (Badan Pusat Statistik Provinsi Bali, 2015).

Seiring meningkatnya jumlah wisatawan, tentu saja jumlah pelayanan pada hotel juga mengalami peningkatan sehingga dibutuhkan tenaga kerja yang lebih banyak. Adanya kebutuhan hotel akan sumber tenaga kerja pada saat tertentu dan juga kebutuhan hotel untuk melakukan efisiensi biaya pengeluaran menyebabkan pihak manajemen hotel dapat mempekerjakan pekerja harian dalam jangka waktu yang lama (Yosua, 2011). Ditinjau dari sudut pengusaha, adanya pekerja harian lepas akan menguntungkan karena pengusaha tidak terbebani biaya tenaga kerja lainnya (Triyono, 2015). Sama halnya seperti pekerja harian, penggunaan karyawan kontrak merupakan hal yang praktis. Hal ini dikarenakanjika karyawan kontrak bekerja tidak sesuai dengan target perusahaan maka kontraknya tidak akan diperpanjang. Perusahaan juga tidak perlu dipusingkan dengan sistem karir, dana pensiun dan lain sebagainya (Hartono, 2013). Berbeda dengan karyawan kontrak dan pekerja harian, secara umum karyawan tetap cenderung merasa lebih aman. Kepastian masa depan kerja karyawan tetap ditentukan oleh sikap positif dalam bekerja dan tidak dibatasi oleh waktu atau masa kontrak.

Fenomena umum pada pengelola atau pengusaha di bidang perhotelan memperkerjakan karyawan dengan status tetap dan tidak tetap. Karyawan dengan status kontrak dibagi menjadi karyawan dengan sistem pemberian gaji bulanan dan harian. Karyawan dengan sistem pemberian gaji harian seringkali disebut sebagai pekerja harian atau dalam perhotelan disebut dengan daily worker (DW). Berdasarkan Undang-Undang Ketenagakerjaan Nomor 13 Tahun 2003, terdapat dua jenis perjanjian kerja yaitu perjanjian kerja waktu tidak tertentu (PKWTT) dan perjanjian kerja waktu tertentu (PKWT). Hal yang membedakan karyawan dengan PKWT dan PKWTT terletak pada perjanjian kerja mengenai masa kerja. Masa kerja karyawan yang terikat dengan PKWT ditetapkan oleh perusahaan. Terdapat beberapa kemungkinan yang akan diterima oleh karyawan ketika kontrak kerja berakhir, yaitu akan diangkat menjadi karyawan tetap, masa kontrak karyawan akan diperpanjang, dan masa kontrak tidak perpanjang. Lain halnya pada karyawan dengan PKWTT, masa kerja antara karyawan dengan perusahaan tidak ditetapkan (Donsari \& Irawati, 2015). Mengacu pada UndangUndang Ketenagakerjaan Nomor 13 Tahun 2003, karyawan tetap termasuk dalam PKWTT, sedangkan karyawan kontrak dan pekerja harian termasuk dalam PKWT.

Salah satu contoh terkait pemberhentian karyawan dengan PKWT oleh pihak perusahaan terjadi pada Hotel Novotel Semarang. Karyawan dengan PKWT melakukan demonstrasi menuntut kejelasan karir dan status pangkat menjadi karyawan tetap. Pada kasus ini sekitar 20 karyawan diputuskan kontrak kerja atau PHK secara sepihak. Salah satu karyawan mengaku telah bekerja hingga delapan tahun, namun tidak diangkat menjadi karyawan dengan PKWTT (Ellya, 2016). Hal serupa juga terjadi pada Perusahaan MNC Sky Vision yang melakukan PHK sepihak terhadap 40 karyawan dengan PKWT, tanpa ada keterangan yang jelas serta tidak ada pesangon yang diberikan oleh perusahaan (Sarina, 2017). Dari gambaran kasus tersebut dapat disimpulkan bahwa karyawan dengan PKWT memiliki ketidakpastian jenjang karir dan masa depan kerja. Masa kerja karyawan dengan PKWT ditentukan oleh perusahaan sesuai dengan perjanjian yang disepakati dengan perusahaan. Ketidakpastian jenjang karir dapat menyebabkan kualitas kehidupan kerja yang rendah. Hal ini didukung oleh penelitian yang dilakukan oleh Rose, Beh, Ulil, dan Idris (2006) menunjukkan bahwa kepuasan karir, pencapaian karir, dan keseimbangan karir memiliki korelasi terhadap kualitas kehidupan kerja.

Kualitas kehidupan kerja merupakan strategi tempat kerja yang mendukung dan memelihara kepuasan karyawan dengan tujuan untuk meningkatkan kondisi kerja karyawan dan organisasi serta keuntungan untuk pemberi kerja (Lau \& May, 1998). Kualitas kehidupan kerja tidak hanya mencakup elemen subjektif dari kepuasan kerja, namun mencakup juga aspek objektif dari kondisi kerja seperti keselamatan, kebersihan, gaji, keamanan, jam kerja, perlatan yang mendukung (Oskamp, 1984). Gurudatt dan Gasal (2015) yang menyebutkan bahwa karyawan yang memiliki beberapa masalah terkait dengan kebijakan promosi, kurangnya langkah-langkah untuk perbaikan kebijakan, ketidakadilan dan diskriminasi menunjukkan kualitas kehidupan kerja yang rendah. Rendahnya gaji yang diterima karyawan juga dapat menurunkan kualitas kehidupan kerja karena gaji merupakan 
salah satu aspek dari kualitas kehidupan kerja yang dipaparkan oleh Denvir, Hillage, Cox, Sinclair, dan Pearman (2007).

Meningkatkan kualitas kehidupan kerja merupakan hal yang tidak mudah di Indonesia, mengingat jam kerja yang panjang serta penghasilan yang rendah masih banyak dialami oleh karyawan di Indonesia. Salah satu contoh di Makassar, karyawan kontrak hanya diberi gaji sebesar Rp. 500.000 per bulan (Yusran, 2015). Kasus lainnya terjadi pada perusahaan PT GSSL, pekerja harian melakukan demonstrasi menuntut kenaikan gaji (Prades, 2016). Adanya kasus demonstrasi yang dilakukan oleh pekerja harian mengindikasikan bahwa gaji yang diterima karyawan masih rendah. Hal ini didukung oleh data dari International Labour Organization (2015) yang menunjukkan bahwa pekerja di Indonesia masih memperoleh upah yang rendah jika dibandingkan negara lainnya.

International Labor Organization (2015) juga menyatakan bahwa jam kerja yang lama dan berlebihan merupakan hal biasa di Indonesia. Hotel merupakan salah satu sektor pekerja di Indonesia yang memiliki jam kerja yang berlebihan (International Labor Organization, 2015). Industri perhotelan dikenal jam kerja yang panjang karena harus melayani pelanggan selama 24 jam. Lingkungan profesional yang ketat, tekanan pekerjaan berat yang mendorong banyak kerja fisik dan mental pada industri perhotelan sehingga diperlukan usaha yang ekstra untuk menyelesaikan pekerjaan (Soni \& Rawal, 2014). Memiliki penghasilan rendah dan jam kerja yang panjang merupakan masalah dalam upayapeningkatan kualitas kehidupan kerja (Saraji \& Dargahi, 2006). Meningkatkan kualitas kehidupan kerja bagi karyawan dalam industri perhotelan merupakan hal yang sangat penting, terlepas dari adanya perbedaan status kerja yang dimiliki oleh karyawan hotel yaitu karyawan dengan PKWTT dan karyawan dengan PKWT. Hal tersebut dikarenakan dalam industri perhotelan, karyawan memiliki peran utama dalam menjalin hubungan antara pelanggan dan organisasi. Pelayanan, sikap, dan perilaku yang ditunjukkan secara signifikan memengaruhi pengalaman dan tingkat kepuasan pelanggan secara keseluruhan (Hunker, 2014).

Terkait penelitian kualitas kehidupan kerja, salah satu hasil penelitian yang dapat diungkap oleh Moradi, Maghaminejad, dan Fini (2014) mengemukakan karyawan dengan PKWTT memiliki kualitas kehidupan kerja yang lebih tinggi dibandingkan dengan karyawan dengan PKWT. Karyawan dengan PKWTT memiliki pendapatan yang lebih tinggi serta prospek karir yang baik dibandingkan dengan karyawan dengan PKWT. Hal serupa juga diungkapkan oleh Gupta dan Gupta (2013) yang mengemukakan adanya perbedaan kualitas kehidupan kerja antara karyawan dengan PKWTT dan karyawan dengan PKWT. Kualitas kehidupan kerja guru yang berstatus karyawan dengan PKWTT lebih tinggi daripada guru yang berstatus karyawan dengan status PKWT. Berdasarkan uraian tersebut menunjukkan adanya indikasi status karyawan sebagai pembeda kualitas kehidupan kerja seseorang.

Kualitas kehidupan kerja secara signifikan memengaruhi perilaku kewargaan organisasi (Nair, 2013). Nair (2013) juga menegaskan bahwa karyawan yang puas dengan kualitas kehidupan kerja memiliki perilaku kewargaan yang lebih tinggi dalam organisasi. Penelitian serupa juga dilakukan oleh Papi dan Nuralizadeh (2014) yang menunjukkan bahwa kualitas kehidupan kerja memiliki pengaruh yang signifikan terhadap perilaku kewargaan organisasi. Menurut Spector (dalam Robbins \& Judge, 2015) mengungkapkan bahwa kepuasan terhadap kualitas kehidupan kerja merupakan faktor penentu perilaku kewargaan organisasi seorang karyawan. Adanya perbedaan kualitas kehidupan kerja dengan status karyawan yang berbeda, dapat memengaruhi perbedaan perilaku kewargaan organisasi pada status karyawan yang berbeda pula.

Perilaku kewargaan organisasi diperlukan pada industri perhotelan karena tujuan utama setiap hotel pada umumnya yaitu memberikan pelayanan yang terbaik dan berkualitas kepada wisatawan (Febriani \& Indrawati 2013). Ma (2011) mengungkapkanuntuk memenuhi atau bahkan melebihi harapan pelanggan, kerap kali karyawan hotel perlu melakukan pekerjaan yang melampaui deskripsi pekerjaanya dengan kata lain karyawan perlu menunjukkan perlaku kewargaan organisasi dalam melayani pelanggan. Karyawan yang memiliki perilaku kewargaan organisasi bermanfaat bagi organisasi, terutama untuk industri perhotelan karena untuk memuaskan pelanggan membutuhkan perilaku yang dapat memenuhi dan melampaui harapan pelanggan (Ma, 2011). Ma (2011) juga menegaskan perilaku kewargaan organisasi juga diperlukan ketika karyawan hotel berinteraksi dan bekerja sama dengan rekan kerja dan supervisor, agar menciptakan pengalaman yang baik bagi pelanggan hotel. Berdasarkan uraian tersebut dapat disimpulkan bahwa perilaku kewargaan organisasi penting dimiliki oleh seluruh karyawan hotel, mengingat tujuan utama setiap hotel adalah memuaskan para pelanggan.

Adanya perbedaan dalam status karyawan hotel dapat menyebabkan perbedaan perilaku kewargaan organisasi antara satu karyawan dengan karyawan lainnya yang memiliki status kerja yang berbeda. Penelitian yang dilakukan Dyne dan Ang (1998) mengungkapkan terdapat perbedaan perilaku kewargaan organisasi pada karyawan dengan PKWTT dan karyawan dengan PKWT. Karyawan dengan PKWTT memiliki perilaku kewargaan organisasi yang lebih tinggi dibandingkan dengan karyawan dengan PKWT. Penelitian serupa dilakukan oleh Widyastutie (2010) yang menunjukkan bahwa terdapat perbedaan perilaku kewargaan organisasi yang sangat signifikan antara karyawan dengan PKWTT dan karyawan dengan PKWT. Karyawan dengan PKWTT memiliki tingkat perilaku kewargaan organisasi yang lebih tinggi dibandingkan dengan karyawan dengan PKWT. Widyastutie (2010) menyebutkan adanya perbedaan status karyawan yang diberikan perusahaan kepada karyawannya merupakan salah satu indikasi dalam pembentukan persepsi karyawan. Adanya perbedaan persepsi sehingga akan memengaruhi pula tingkat perilaku kewargaan organisasi yang berbeda pada karyawan dengan PKWTT dan karyawan PKWT.

Disisi lain, meskipun hasil penelitian menujukkan bahwa karyawan dengan PKWTT memiliki perilaku kewargaan organisasi yang lebih tinggi, namun terdapat beberapa hotel 
yang hanya mempekerjakan karyawan dengan PKWT. Berdasarkan studi pendahuluan yang dilakukan dalam penelitian ini menemukan bahwa Hotel Fontana dan Hotel The Kana tidak mempekerjakan karyawan dengan PKWTT. Hotel Fontana ini hanya mempekerjakan karyawan dengan PKWT. Karyawan dengan PKWT yang bekerja pada Hotel Fontana berjumlah 99 orang yang terdiri dari 77 karyawan kontrak dan 22 pekerja harian. Samahalnya dengan Hotel Fontana, pada Hotel The Kana juga tidak mempekerjakan karyawan dengan PKWTT. Jumlah karyawan dengan PKWT pada Hotel The Kana adalah 127 terdiri dari 104 karyawan kontrak dan 23 pekerja harian. Menurut seorang staff human reources Hotel Fontana, antara karyawan kontrak dan pekerja harian dapat menyelesaikan tugasnya tepat waktu dan mematuhi aturan, hotel ini tetap dapat beroperasi dengan baik.

Berdasarkan hasil wawancara dengan dua orang pekerja harian yang bekerja di hotel, tidak dipungkiri bahwa terdapat perbedaan antara karyawan dengan PKWTT dan karyawan dengan PKWT. Adapun perbedaan tersebut dalam hal gaji yang diterima dan pemilihan shift kerja, namun pekerjaan yang dilakukan sama antara karyawan dengan PKWTT dan karyawan dengan PKWT (Widiastuti, 2016). Hal tersebut tidak membuat perilaku kewargaan organisasi pekerja harian tersebut rendah, hal ini ditunjukkan dengan adanya kemauan untuk bekerja lembur, menggantikan rekan kerja yang sakit, serta memiliki kemauan untuk mengajari karyawan baru. Membantu karyawan baru menggambarkan salah satu dimensi dari perilaku organisasi yaitu helping behavior, serta menggantikan rekan kerja yang sakit dan bersedia untuk bekerja lembur merupakan gambaran dari dimensi individual initiative yang dipaparkan oleh Podsakoff, MacKenzie, Paine, dan Bachrach (dalam Riggio, 2009). Kedua pekerja harian tersebut mengaku bahwa hal tersebut dilakukan untuk mendapatkan promosi jabatan serta diperpanjang masa kontrak kerjanya (Widiastuti, 2016).

Terbatasnya penelitian yang membahas karyawan dengan PKWT khususnya pekerja harian maka sebagai studi awal, selain melakukan wawancara, dilakukan survei untuk melihat gambaran pekerja harian dengan cara menyebarkan kuisioner mengenai kepuasan kerja pada 30 responden yang bekerja sebagai pekerja harian di hotel. Secara keseluruhan pekerja harian merasa puas terhadap pekerjaannya, namun terdapat skor yang rendah pada aitem yang berkaitan dengan gaji, sedangkan skor tertinggi pada aitem rekan kerja dan lingkungan tempat bekerja (Widiastuti, 2016). Hal ini sejalan dengan penelitian yang dilakukan oleh Puspitawati (2013) pada karyawan Hotel Bali Hyatt Sanur didapatkan hasil secara keseluruhan penilaian karyawan terhadap kepuasan kerja baik namun terdapat nilai terendah pada aitem pertanyaan perbandingan gaji dengan perusahaan lain yang sejenis. Hal ini menunjukkan pekerja harian memiliki gaji yang lebih rendah dibandingkan karyawan dengan PKWTT. Perbedaan gaji yang diterima akan memengaruhi kualitas kehidupan kerja, mengingat aspek gaji merupakan salah satu dimensi dari kualitas kehidupan kerja yang dipaparkan oleh Denvir, Hillage, Cox, Sinclair, dan Pearman (2007).
Selain gaji yang lebih tinggi, kejelasan karir serta masa kerja yang tidak terikat jangka waktu tertentu menyebabkan karyawan dengan PKWTT memiliki kualitas kehidupan kerja dan perilaku kewargaan organisasi yang lebih tinggi dibandingkan dengan karyawan dengan PKWT. Penelitian sebelumnya telah menjelaskan bahwa karyawan dengan PKWTT memiliki perilaku kewargaan organisasi dan kualitas kehidupan kerja yang lebih baik dibandingkan dengan karyawan dengan PKWT. Disisi lain dapat dilihat beberapa hotel di Bali, memilih hanya mempekerjakan karyawan dengan status PKWT dan hasil wawancara pada pekerja harian menunjukkan bahwa pekerja harian memiliki perilaku kewargaan organisasi yang tinggi. Saat ini, adanya gambaran yang beragam terkait dengan perilaku kewargaan organisasi dan kualitas kehidupan kerja pada karyawan dengan PKWTT dan karyawan dengan PKWT menjadi dasar dilakukannya penelitian ini. Diharapkan hasil penelitian ini dapat memberikan gambaran atas fenomena pada preliminary study serta menjadi gambaran atas keberagaman kualitas kehidupan kerja dan perilaku kewargaan organisasi yang dimiliki karyawan dengan PKWTT dan karyawan dengan PKWT pada hotel di Bali.

\section{METODE PENELITIAN}

\section{Variabel dan Definisi Operasional}

Variabel terikat dalam penelitian ini adalah perilaku kewargaan organisasi, sedangkan variabel bebas dalam penelitian ini adalah status kerja karyawan dan kovariabel dalam penelitian ini adalah kualitas kehidupan kerja. Definisi operasional dari masing- masing variabel penelitian adalah sebagai berikut:

Perilaku kewargaan organisasi

Perilaku kewargaan organisasi merupakan perilaku karyawan yang secara sukarela memberikan kontribusi pada organisasi melebihi persyaratan kerja formal dan melibatkan usaha ekstra yang tanpa mendapat imbalan secara langsung dari organisasi. Skala yang digunakan untuk mengungkap PKO dalam penelitian ini mengacu pada teori yang dikemukan oleh Podsakoff, dkk. (dalam Riggio, 2009) yang terdiri dari tujuh dimensi, yaitu: helping behavior, sportmanship, organizational loyalty, organizational compliance, individual initiative, civic virtue, self development.

Status kerja karyawan

Status kerja karyawan adalah status yang membedakan jenis masa kerja karyawan dalam suatu perusahaan atau organisasi menurut waktu yang telah ditentukan oleh kedua belah pihak berdasarkan perjanjian kerja yang telah disepakati oleh keduabelah pihak, yang terdiri dari karyawan PKWTT dan karyawan dengan PKWT. Berdasarkan Undang-Undang Ketenagakerjaan Nomor 13 tahun 2003 maka dapat dipaparkan definisi operasional karyawan dengan PKWTT dan karyawan dengan PKWT adalah sebagai berikut:Pertama, karyawan dengan PKWTT adalah karyawan yang telah memenuhi syarat yang ditentukan, diterima, dipekerjakan dan mendapatkan upah atau gaji, terikat dalam hubungan kerja dengan perusahaan untuk jangka waktu yang tidak tertentu.Kedua, karyawan dengan PKWT merupakan karyawan yang terikat dalam hubungan kerja secara terbatas dengan perusahaan atas dasar perjanjian kerja untuk jangka waktu tertentu. Dalam industri perhotelan karyawan dengan 
PKWT dibagi menjadi karyawan kontrak dan pekerja harian atau yang sering disebut dengan daily worker.

Kualitas kehidupan kerja

Kualitas kehidupan kerja merupakan program kerja yang komprehensif bertujuan untuk membantu karyawan menjadi lebih baik dalam mengelola perubahan dan transisi sehingga menimbulkan persepsi karyawan tentang kesejahteraan mental dan fisiknya ketika bekerja. Skala yang digunakan untuk mengungkap kualitas kehidupan kerja dalam penelitian ini mengacu pada teori yang dikemukan oleh Denvir et al (2007) yang terdiri dari delapan dimensi, yaitu: leadership and the organisation, management, working conditions, rewards and fairness, skills and prospects, relations at work, nature of work, organisation of work.

\section{Responden}

Populasi yang ditargetkan dalam penelitian ini adalah seluruh karyawan yang bekerja pada hotel di Bali. Karakteristik populasi yang digunakan dalam penelitian ini yaitu karyawan hotel di Bali yang berada dalam rentang usia kerja, minimal memiliki pendidikan SMA atau SMK.

Sampel pada penelitian ini diambil dengan metode pengambilan sampel secara acak dengan menggunakan cluster random sampling. cluster random sampling pada di penelitian ini dilakukan dengan dua tahap, atau yang biasa disebut twostages cluster sampling. Tahap pertama dilakukan undian untuk menentukan daerah sampel. Provinsi Bali terdiri dari delapan kabupaten dan satu kotamadya, sehingga undian dilakukan dengan membuat nama masing-masing kabupaten dan satu kotamadya tersebut pada satu lembar kertas lalu digulung dan dimasukan kedalam botol. Nama kabupaten atau kotamadya yangkeluar setelah diundi adalah Kota Denpasar, sehingga dalam penelitian ini Kota Denpasar terpilih menjadi daerah sampel.

Tahap kedua dilakukan pengacakan kembali untuk menentukan hotel yang menjadi daerah sampel. Pengacakan dilakukan berdasarkan Direktori Dinas Pariwisata Provinsi Bali tahun 2016, pada kota Denpasar terdapat 223 hotel. Peneliti melakukan pengacakan dengan cara memilih hotel yang memiliki nomor urut ganjil. Hotel-hotel yang memberikan izin diantaranya: Inna Sindhu Beach, Griya Santrian, Sanur Paradise Hotel\& Suites, Sanur Village, Swastika Bungalow, Parigata Resort. Masih belum terpenuhinya syarat minimal sampel yang digunakan, peneliti kembali melakukan pengacakan pada hotel yang memiliki nomor urut genap. Adapun hotel yang memberikan izin diantaranya: POP! Hotel, Prama Sanur Beach, Taman Agung Beach, Grand Mirah, dan Nikki. Peneliti menyebarkan kuesioner yang berisi dua skala kepada 11 hotel, jumlah kuisioner yang tersebar adalah sebanyak 158 kuisioner, namun hanya 126 kuisioner yang dapat dianalisis.

\section{Tempat Penelitian}

Penelitian ini dilakukan di beberapa hotel yang ada di Kotamadya Denpasar. Pada tahap pertama Kotamadya Denpasar terpilih sebagai area dalam penelitian. Pada tahap kedua terpilih sebelas hotel di Denpasar, yaitu: Inna Sindhu Beach, Griya Santrian, Sanur Paradise Hotel \& Suites, Sanur
Village, Swastika Bungalow, Parigata Resort, POP! Hotel, Prama Sanur Beach, Taman Agung Beach, Grand Mirah, Nikki. Pengambilan data berlangsung selama 1,5 bulan, dimulai pada tanggal 2 Juni 2017 hingga 13 Juli 2017.

\begin{abstract}
Alat Ukur
Alat ukur penelitian ini menggunakan skala perilaku kewargaan organisasi dan skala kualitas kehidupan kerja. Skala perilaku kewargaan organisasi yang digunakan dalam penelitian ini mengacu pada teori yang dikemukan oleh Podsakoff, dkk. (dalam Riggio, 2009) yang terdiri dari tujuh dimensi yaitu: helping behavior, sportmanship, organizational loyalty, organizational compliance, individual initiative, civic virtue, self development. Skala kualitas kehidupan kerja yang digunakan dalam penelitian ini mengacu pada Denvir, dkk. (2007) yang terdiri dari delapan dimensi yaitu: leadership and the organisation, management, working conditions, rewards and fairness, skills and prospects, relations at work, nature of work, organisation of work.
\end{abstract}

Skala perilaku kewargaan organisasi terdiri dari 50 aitem pernyataan dan skala kualitas kehidupan kerja terdiri dari 92. Kedua skala tersebut terdiri dari pernyataan positif(favorable) dan pernyataan negatif (unfavorable) dengan empat pilihan jawaban yaitu Sangat Setuju (SS), Setuju (S), Tidak Setuju (TS), dan Sangat Tidak Setuju (STS).

Pada penelitian ini dilakukan serangkaian uji validitas dan reliabilitas yang dilakukan pada tanggal 11 hingga $25 \mathrm{Mei}$ 2017. Uji validitas dilakukan dengan teknik professional judgement dan dengan pengujian daya diskriminasi aitem yang dilakukan dengan cara menghitung koefisien korelasi antara distribusi skor aitem. Koefisien korelasi aitem total dan korelasi aitem antar aspek dinyatakan valid dengan batasan minimum $>0,30$ (Azwar, 2015). Pengujian reliabilitas dilakukan dengan metode Alpha Cronbach. Kriteria suatu skala dikatakan reliabel dengan menggunakan teknik ini, apabila koefisien reliabilitas menunjukkan angka lebih dari 0,6 (Azwar, 2015).

Hasil uji validitas yang dilakukan pada skala perilaku kewargaan organisasi menunjukkan nilai koefisien korelasi aitem total yang bergerak dari 0,312 sampai 0,837 . Sementara itu, hasil uji reliabilitas pada skala perilaku kewargaan organisasi menunjukkan nilai Cronbach's Alpha sebesar 0,971 yang berarti bahwa skala ini mampu mencerminkan 97,1\% dari variasi pada skor murni subjek. Hasil tersebut menunjukkan bahwa skala ini dapat digunakan untuk mengukur perilaku kewargaan organisasi.

Hasil uji validitas yang dilakukan pada skala kualitas kehidupan kerja menunjukkan nilai koefisien korelasi aitem total yang bergerak dari 0,302 sampai 0,888 . Sementara itu, hasil uji reliabilitas pada skala kualitas kehidupan kerja menunjukkan nilai Cronbach's Alpha sebesar 0,982 yang berarti bahwa skala ini mampu mencerminkan 98,2\% dari variasi skor murni subjek. Hasil tersebut menunjukkan bahwa skala ini dapat digunakan untuk mengukur kualitas kehidupan kerja. 


\section{Teknik Analisis Data}

Sebelum melakukan uji hipotesis untuk memastikan data penelitian yang telah diperoleh dapat diolah, maka dilakukan uji asumsi yang terdiri dari uji normalitas, uji homogenitas, uji linieritas, dan uji multikolinieritas. Uji normalitas pada penelitian ini menggunakan uji Kolmogorov-Smirnov, uji linieritas dilakukan dengan menggunakan uji compare means, uji homogenitas dilakukan dengan menggunakan uji Levene test, uji multikolinieritas dilakukan dengan melihat nilai variance inflation factor (VIF). Setelah melakukan uji asumsi, data penelitian dianalisis dengan menggunakan metode uji ANCOVA (Analysis of Covariance) untuk menguji hipotesis mayor, sedangkan uji hipotesis minor dianalisis menggunakan independent sample t-test dan uji regresi. Analisis data dilakukan dengan menggunakan bantuan program SPSS 21.0 for Windows.

\section{HASIL PENELITIAN}

\section{Karakteristik Subjek}

Berdasarkan data karakteristik subjek, subjek dalam penelitian ini berjumlah 126 orang yang terdiri dari 64 karyawan dengan PKWTT dan 62 karyawan dengan PKWT. Mayoritas karyawan dengan PKWTT, berjenis kelamin laki-laki, memiliki pendidikan terakhir SMA atau SMK, bekerja pada hotel bintang lima dan hotel melati, lama bekerja lebih dari sepuluh tahun, dan memiliki rentang usia antara 41 sampai 50 tahun. Sementara itu, mayoritas karyawan dengan PKWT, berjenis kelamin laki-laki, memiliki pendidikan terakhir SMA atau SMK, bekerja pada hotel melati, lama bekerja antara satu hingga tiga tahun, dan memiliki rentang usia antara 21 sampai 30 tahun

\section{Deskripsi Data Penelitian}

Hasil deskripsi statistik data penelitian variabel perilaku kewargaan organisasi dirangkum dalam tabel 1 (terlampir) dan variabel kualitas kehidupan kerja dalam tabel 2 (terlampir).

Berdasarkan tabel 1, terlihat bahwa pada kelompok karyawan dengan PKWTT sebaran data berkisar antara 131 sampai dengan 195, sementara pada kelompok karyawan dengan PKWT sebaran data berkisar antara 140 sampai dengan 194. Skor perilaku kewargaan organisasi terendah pada subjek penelitian berada pada kelompok karyawan dengan PKWTT, sedangkan skor perilaku kewargaan organisasi tertinggi juga berada pada kelompok karyawan dengan PKWTT. Mean teoretis pada kedua kelompok adalah sebesar 125 sementara mean empiris pada kelompok karyawan dengan PKWTT sebesar 169,84 dan pada kelompok karyawan dengan PKWT sebesar 160,60. Mean empiris yang didapat lebih besar dari mean teoretis dan berbeda secara signifikan, sehingga menghasilkan sebuah kesimpulan bahwa kedua kelompok subjek memiliki taraf perilaku kewargaan organisasi yang tinggi.

Berdasarkan tabel 2, terlihat bahwa pada kelompok karyawan dengan PKWTT sebaran data berkisar antara 261 sampai dengan 358, sementara pada kelompok karyawan dengan PKWT sebaran data berkisar antara 234 sampai dengan 345. Skor kualitas kehidupan kerja terendah pada subjek penelitian berada pada kelompok karyawan dengan PKWT, sedangkan skor kualitas kehidupan kerja tertinggi berada pada kelompok karyawan dengan PKWTT. Mean teoretis pada kedua kelompok adalah sebesar 230 sementara mean empiris pada kelompok karyawan dengan PKWTT sebesar 297,30 dan pada kelompok karyawan dengan PKWT sebesar 288,53. Mean empiris yang didapat lebih besar dari mean teoretis dan berbeda secara signifikan, sehingga menghasilkan sebuah kesimpulan bahwa kedua kelompok subjek memiliki taraf kualitas kehidupan kerja yang tinggi.

\section{Uji Asumsi}

Uji normalitas data dilakukan untuk mengetahui normal atau tidak normalnya sebaran data penelitian. Uji normalitas pada penelitian ini dilakukan dengan menggunakan uji Kolmogorov-Smirnov melalui program SPSS versi 21.0 for windows. Uji normalitas data penelitian telah dirangkum pada tabel 3 (terlampir). Berdasarkan uji normalitas yang telah dirangkum pada tabel 3, pada kolom kolmogorov-smirnov variabel perilaku kewargaan organisasi, diperoleh skor kolmogorov- smirnov sebesar 1,047 dengan signifikansi 0,223 $(\mathrm{p}>0,05)$, sehingga dapat dikatakan bahwa sebaran data variabel perilaku kewargaan organisasi bersifat normal. Pada kolomKolmogorov-Smirnov variabel kualitas kehidupan kerja, diperoleh skor sebesar 0,966 dengan signifikansi 0,308 $(\mathrm{p}>0,05)$, sehingga dapat dikatakan bahwa sebaran data variabel kualitas kehidupan kerja pada kedua kelompok bersifat normal.

Uji homogenitas digunakan untuk menguji data sampel yang diambil memiliki varian yang sama atau tidak. Hasil uji homogenitas pada penelitian ini dilakukan dengan melihat tabel Levene Test. Hasil tabel Levene Test dirangkum dalam tabel 4 (terlampir). Hasil uji Levene pada variabel perilaku kewargaan organisasi menunjukkan angka 0,591 dengan signifikansi sebesar 0,443 ( $\mathrm{p}>0,05)$, sehingga dapat dikatakan bahwa sebaran data variabel perilaku kewargaan organisasi bersifat homogen. Pada variabel kualitas kehidupan kerja menunjukkan angka 1,190 dengan signifikansi sebesar 0,277 $(\mathrm{p}>0,05)$, sehingga dapat dikatakan bahwa sebaran data variabel kualitas kehidupan kerja bersifat homogen. Tidak adanya perbedaan varian pada variabel perilaku kewargaan organisasi dan kualitas kehidupan kerja, sehingga dapat ditarik kesimpulan bahwa data berasal dari populasi dengan varian yang sama atau homogen.

Uji linieritas dilakukan untuk melihat hubungan linier antar variabel dalam penelitian. Uji linieritas dilakukan dengan menggunakan uji compare mean dengan bantuan program SPSS 21.0 for Windows. Dapat dikatakan adanya hubungan yang linier apabila nilai signifikansi yang diperoleh kurang dari 0,05. Hasil uji linieritas data dapat dilihat pada tabel 5 (terlampir). Berdasarkan hasil uji lineritas data pada tabel 5, variabel perilaku kewargaan organisasi dan kualitas kehidupan kerja memiliki hubungan yang linier karena nilai signifikansi pada kolom linearity menunjukkan angka 0,000 $(\mathrm{p}<0,05)$, dan nilai signifikansi pada kolom deviation from linearity menunjukkan angka $0,199(\mathrm{p}>0,05)$.

Uji multikolinieritas bertujuan untuk mengetahui apakah terdapat korelasi antar variabel bebas pada model regresi. Metode regresi dianggap baik jika data tidak memiliki 
multikolonieritas yang ditandai dengan nilai VIF yang berada dibawah 10 dan nilai collinearity tolerance diatas 0,1 (Ghozali, 2012). Hasil uji multikolonieritas dapat dilihat pada tabel 6 (terlampir). Berdasarkan hasil uji multikolonieritas data penelitian pada tabel 6 , dapat dinyatakan bahwa tidak terjadi multikolonieritas diantara kedua variabel penelitian. Hal ini ditunjukkan dengan nilai VIF sebesar 1,000 (dibawah 10) dan nilai tolerance sebesar 1,000 (diatas 0,1 ).

\section{Uji Hipotesis}

Uji hipotesis digunakan untuk mengetahui hipotesis yang diajukan peneliti pada penelitian diterima atau ditolak. Terdapat dua pengujian dalam penelitian ini, pertama pengujian hipotesis mayor dengan analysis of covariance (ANCOVA). ANCOVA merupakan perpanjangan dari analysis of variance (ANOVA) yang memasukan variabel independen metrik sebagai covariate kedalam model (Ghozali, 2012). Analisis dilakukan dengan bantuan SPSS versi 21.0 for windows. Hasil uji ANCOVA dengan dapat dilihat pada tabel 7 (terlampir).

Hasil uji dari hipotesis yang diajukan dalam penelitian ini dapat dilihat pada tabel 7 (terlampir). Pada tabel tersebut terdapat nilai corrected model yang merupakan nilai pengaruh semua variabel independen secara simultan atau bersamasama terhadap variabel dependen. Artinya, nilai corrected model pada tabel 7 adalah nilai dari variabel status kerja karyawan dan kualitas kehidupan kerja secara bersama-sama berpengaruh terhadap perilaku kewargaan organisasi. Nilai signifikansi pada corrected model adalah sebesar $\mathrm{p}=0,000(\mathrm{p}$ $<0,05)$, sehingga kesimpulan yang diperoleh adalah H0 di tolak dan $\mathrm{Ha}$ diterima. Hasil tersebut menunjukkan bahwa kualitas kehidupan kerja dan status kerja karyawan memberikan kontribusi terhadap tingkat perilaku kewargaan organisasi.

Perbedaan juga dapat dilihat pada nilai adjusted $R$ squared antara dilakukan dan tidak dilakukannya kontrol pada kualitas kehidupan kerja. Pada saat tidak dilakukan kontrol pada kualitas kehidupan kerja, nilai adjusted $R$ squared perilaku kewargaan organisasi jika ditinjau dari status kerja karyawan saja memiliki nilai sebesar 0,085. Nilai tersebut berarti bahwa variabel perilaku kewargaan organisasi hanya dapat dijelaskan oleh variabel status kerja karyawan sebesar 8,5\%, setelah dilakukan kontrol pada kualitas kehidupan kerja terjadi kenaikan nilai adjusted $R$ squared menjadi 0,665. Nilai tersebut berarti bahwa variabel perilaku kewargaan organisasi dapat dijelaskan oleh variabel status kerja karyawan dan kualitas kehidupan kerja sebesar 66,5\%. Adanya kenaikan sebesar 58,0\% setelah dilakukan kontrol terhadap kualitas kehidupan kerja menandakan bahwa model menjadi lebih baik yang berarti tingkat kesalahan dalam uji ini dapat diminimalisir. Tabel 8 (terlampir) menunjukkan uji hipotesis mayor tanpa adanya kontrol terhadap kualitas kehidupan kerja.

Pengujian hipotesis kedua adalah uji hipotesis minor yaitu uji komparasi dan regresi sederhana. Uji komparasi dilakukan dengan tujuan untuk membuktikan hipotesis minor yang pertama dan yang kedua. Hipotesis minor yang pertama yaitu ada perbedaan perilakukewargaan organisasi antara karyawan dengan PKWTT dan karyawan dengan PKWT. Hipotesis minor yang kedua yaitu ada perbedaan kualitas kehidupan kerja antara karyawan dengan PKWTT dan karyawan dengan PKWT. Hipotesis minor ketiga diuji menggunkan uji regresi yang bertujuan untuk mengetahui kontribusi kualitas kehidupan kerja terhadap perilaku kewargaan organisasi.

Uji hipotesis minor yang pertama dan kedua komparasi dilakukan dengan metode analisis independent sample t-test dengan bantuan perangkat lunak SPSS 21.0 for windows. Tujuan dari uji hipotesis adalah untuk mengetahui apakah terdapat perbedaan rata-rata antara dua kelompok penelitian. Hasil uji independent sample t-test yang telah dilakukan dirangkum dalam tabel 9 (terlampir).

Berdasarkan tabel 9 dapat dilihat, $F$ hitung pada variabel perilaku kewargaan organisasi menunjukkan angka 0,591 dan t hitung adalah sebesar 3,545 dengan signifikansi sebesar 0,001. Variabel kualitas kehidupan kerja menunjukkan $\mathrm{F}$ hitung sebesar 1,190 dan $t$ hitung sebesar 2,021 dengan signifikansi sebesar 0,045. Kedua variabel menunjukan angka signifikansi dibawah 0,05 $(\mathrm{p}<0,05)$ maka dapat diartikan Ho ditolak pada kedua variabel yang diukur yaitu perilaku kewargaan organisasi dan kualitas kehidupan kerja. Hal ini berarti terdapat perbedaan perilaku kewargaan organisasi dan kualitas kehidupan kerja antara karyawan dengan PKWTT dan karyawan dengan PKWT yang bekerja pada hotel di Bali.

Pengujian hipotesis minor ketiga adalah uji regresi sederhana untuk variabel kualitas kehidupan kerja terhadap perilaku kewargaan organisasi. Tujuan dari uji hipotesis adalah untuk melihat keeratan hubungan antar variabel dan juga untuk memprediksi hubungan antar variabel. Hasil uji regresi yang telah dilakukan dan telah dirangkum dalam tabel 10, tabel 11, dan tabel 12 (terlampir).

Berdasarkan tabel 10, dapat dilihat bahwa terdapat nilai $\mathrm{R}$ yang merupakan koefisien regresi sebesar 0,802 dan nilai adjusted $R$ square (R2) yang merupakan nilai koefisien determinasi sebesar 0,644. Nilai adjusted R2 menunjukkan besarnya peran atau sumbangan dari variabel bebas terhadap variabel tergantung. Nilai adjusted R2 sebesar 0,641 berarti bahwa pengaruh kualitas kehidupan kerja terhadap perilaku kewargaan organisasi adalah sebesar $64,1 \%$, sedangkan $35,9 \%$ dipengaruhi oleh faktor-faktor lain diluar penelitian ini.Nilai signifikansi $\mathrm{F}$ yang dihasilkan dari uji regresi pada tabel 11 adalah sebesar $0,000(\mathrm{p}<0,05)$. Hasil ini menunjukkan bahwa model regresi dalam penelitian ini dapat digunakan untuk memprediksi variabel terikat yaitu perilaku kewargaan organisasi.

Nilai t sebesar 14,968 dan nilai signifikansi sebesar 0,000 $(\mathrm{p}<0,05)$ menunjukkan bahwa kualitas kehidupan kerja berkontribusi secara signifikan terhadap perilaku kewargaan organisasi.

Berdasarkan hasil uji ANCOVA, independent sample t-test, dan uji regresi yang telah didapatkan, maka rangkuman hipotesis mayor dan minor penelitian ini dapat dilihat pada tabel 13 (terlampir).

PEMBAHASAN DAN KESIMPULAN 
Berdasarkan hasil penelitian yang telah dianalisis dengan menggunakan uji ANCOVA, dapat diketahui bahwa hipotesis mayor penelitian yaitu ada perbedaan perilaku kewargaan organisasi berdasarkan status kerja karyawan hotel di Bali ditinjau dari kualitas kehidupan kerja dapat diterima. Hal ini dapat dilihat dari angka signifikansi yang menunjukkan 0,000 dan dengan nilai $\mathrm{F}$ sebesar 124,956. Hasil ini menunjukkan bahwa pada tingkat kepercayaan 95\% kualitas kehidupan kerja dan status kerja karyawan memiliki kontribusi terhadap perilaku kewargaan organisasi pada karyawan hotel di Bali. Nilai adjusted $R$ squared sebesar 0,665 memiliki arti bahwa variabel perilaku kewargaan organisasi dapat dijelaskan oleh variabel kualitas kehidupan kerja dan status kerja karyawan adalah sebesar 66,5\%. Sebesar 33,5\% lainnya variabel perilaku kewargaan organisasi dipengaruhi oleh variabel lain yang tidak diteliti dalam penelitian ini.

Perilaku kewargaan organisasi hanya dapat dijelaskan sebesar $8,5 \%$ oleh variabel status kerja karyawan. Kontribusi tersebut dapat dilihat pada nilai adjusted $R$ squared sebesar 0,085 sebelum dilakukan kontrol terhadap variabel kualitas kehidupan kerja. Status kerja karyawan adalah status yang membedakan jenis masa kerja karyawan dalam suatu perusahaan atau organisasi menurut waktu yang telah ditentukan oleh kedua belah pihak berdasarkan perjanjian kerja yang telah disepakati oleh kedua belah pihak. Kontribusi status kerja karyawan terhadap perilaku kewargaan organisasi, dapat dilihat dengan adanya perbedaan perilaku kewargaan organisasi berdasarkan status kerja karyawan. Hal ini sejalan dengan penelitian yang dilakukan oleh Chang dan Chelladura (2003) menunjukkan adanya perbedaan perilaku kewargaan organisasi berdasarkan status kerja karyawan. Kecilnya kontribusi status kerja karyawan juga dapat dilihat dari adanya persamaan padataraf perilaku kewargaan organisasi pada kedua kelompok subjek yaitu tidak ada yang memiliki taraf perilaku kewargaan organisasi yang sangat rendah dan rendah. Berdasarkan studi pendahuluan yang telah dilakukan diduga penyebab rendahnya kontribusi status kerja karyawan terhadap perilaku kewargaan organisasi yaitu: tidak ada perbedaan pembagian tugas antara karyawan dengan PKWTT dan karyawan dengan PKWT. Disisi lain, karyawan dengan PKWT ingin karirnya berkembang dan memiliki memiliki masa depan kerja yang layak sehingga mendorong karyawan PKWT untuk menampilkan perilaku kewargaan organisasi (Widiastuti, 2016).

Nilai perilaku kewargaan organisasi meningkat menjadi 0,665 setelah adanya kontrol pada kualitas kehidupan kerja, menunjukkan bahwa kualitas kehidupan kerja lebih berperan dibanding status kerja karyawan terhadap perilaku kewargaan organisasi. Adanya kenaikan nilai adjusted $R$ squared sebesar $58 \%$ menandakan bahwa model regresi menjadi lebih baik. Kontribusi kualitas kehidupan kerja dapat dilihat dari hasil $\mathrm{F}$ hitung sebesar 215,603 dan nilai signifikansi sebesar 0,000 menunjukkan bahwa kualitas kehidupan kerja secara signifikan berinteraksi dengan perilaku kewargaan organisasi. Hal ini didukung oleh penelitian dilakukan oleh Papi dan Nuralizadeh (2014) yang menunjukkan bahwa kualitas kehidupan kerja memiliki pengaruh yang signifikan terhadap perilaku kewargaan organisasi. Karyawan yang memiliki kualitas kehidupan kerja yang tinggi akan mendorong timbulnya perilaku kewargaan organisasi (Jati, 2013). Penelitian serupa juga dilakukan Asgari, Taleghani, dan Abadikhah (2012) yang menunjukkan pula adanya pengaruh kualitas kehidupan kerja terhadap perilaku kewargaan organisasi.

Adapun penelitian dari Ngugi (2017) menunjukkan bahwa kondisi kerja yang merupakan salah satu dimensi dari kualitas kehidupan kerja yang dapat memunculkan perilaku kewargaan organisasi. Dimensi kualitas kehidupan kerja yang lainnya seperti reward and fairness juga memiliki kontribusi terhadap perilku kewargaan organisasi. Hal ini sejalan dengan penelitian Khanifar (2013) menemukan bahwa adanya pengaruh positif dari kompensasi berbasis kinerja terhadap perilaku kewargaan organisasi. Organisasi yang memiliki sistem kompensasi dengan cara memberikan bonus sesuai dengan kinerja karyawannya, dapat mendorong karyawan untuk menampilkan perilaku kewargaan oraganisasi (Alkahtani, 2015). Adanya beberapa penelitian yang menunjukkan bahwa dimensi dari kualitas kehidupan kerja memiliki pengaruh terhadap perilaku kewargaan organisasi, diduga hal tersebut menyebabkan kontribusi kualitas kehidupan kerja terhadap perilaku kewargaan organisasi lebih besar dibandingkan dengan kontribusi dari status kerja karyawan.

Uji hipotesis minor pertama dilakukan dengan uji komparasi pada variabel perilaku kewargaan organisasi yang menunjukkan bahwa ada perbedaan perilaku kewargaan organisasi antara karyawan dengan PKWTT dan karyawan dengan PKWT pada hotel di Bali. Hal ini dapat dilihat dari angka signifikansi yang menunjukkan $0,001 \quad(p<0,05)$ yang berarti ada perbedaan perilaku kewargaan organisasi antara karyawan dengan PKWTT dan karyawan dengan PKWT. Hal ini sejalan dengan penelitian yang dilakukan Dyne dan Ang (1998) mengungkapkan ada perbedaan perilaku kewargaan organisasi pada karyawan dengan PKWTT dan karyawan dengan PKWT. Penelitian serupa dilakukan oleh Widyastutie (2010) yang menunjukkan bahwa ada perbedaan perilaku kewargaan organisasi yang sangat signifikan antara karyawan dengan PKWTT dan karyawan dengan PKWT.

Karyawan dengan PKWTT yang bekerja pada hotel Bali menunjukkan perilaku kewargaan organisasi yang lebih tinggi dibanding dengan karyawan dengan PKWT yang bekerja pada hotel di Bali. Hal ini dapat dilihat dari rata-rata skor perilaku kewargaan organisasi yang dimiliki kedua kelompok. Kelompok karyawan dengan PKWTT menunjukkan skor ratarata perilaku kewargaan organisasi sebesar 169,84, sedangkan kelompok karyawan dengan PKWT menunjukkan skor ratarata perilaku kewargaan organisasi sebesar 160,60. Hal ini sejalan dengan penelitian yang dilakukan Onyishi (2010) menunjukkan bahwa karyawan dengan PKWTT menunjukkan perilaku kewargaan organisasi yang lebih tinggi daripada karyawan dengan PKWT. Dyne dan Ang (1998) juga menyatakan bahwa karyawan dengan PKWTT memiliki perilaku kewargaan organisasi yang lebih tinggi dibandingkan dengan karyawan dengan PKWT. Menurut Organ (dalam Organ, dkk., 2006) karyawan yang memiliki perilaku yang tinggi akan menunjukkan sikap seperti : suka meonolong karyawan lain, memiliki sikap sportif, tetap setia pada 
organisasi, bekerja dengan maksimal, memiliki inisiatif, aktif berpartisipasi terhadap organisasi, serta secara sukarela meningkatkan kemampuan yang dimiliki.

Uji hipotesis minor kedua dilakukan juga uji komparasi pada variabel kualitas kehidupan kerja yang menunjukkan bahwa ada perbedaan kualitas kehidupan kerja antara karyawan dengan PKWTT dan karyawan dengan PKWT pada hotel di Bali. Hal ini dilihat dari dari angka signifikansi yang menunjukkan $0,045(\mathrm{p}<0,05)$ yang berarti ada perbedaan kualitas kehidupan kerja antara karyawan dengan PKWTT dan karyawan dengan PKWT. Sejalan dengan penelitian yang dilakukan oleh Putri (2015) yang mengungkapkan bahwa terdapat perbedaan kualitas kehidupan kerja antara karyawan dengan PKWTT dan karyawan PKWT. Hal serupa juga diungkapkan oleh Gupta dan Gupta (2013) yangmengemukakan adanya perbedaan kualitas kehidupan kerja antara karyawan dengan PKWTT dan karyawan dengan PKWT.

Karyawan dengan PKWTT yang bekerja pada hotel Bali menunjukkan kualitas kehidupan kerja yang lebih tinggi dibanding dengan karyawan dengan PKWT yang bekerja pada hotel di Bali. Hal ini dapat dilihat dari rata-rata skor kualitas kehidupan kerja yang dimiliki kedua kelompok. Kelompok karyawan dengan PKWTT menunjukkan skor rata- rata kualitas kehidupan kerja sebesar 297,30, sedangkan kelompok karyawan dengan PKWT menunjukkan skor rata-rata kualitas kehidupan kerja sebesar 288,53. Kualitas kehidupan kerja guru yang berstatus karyawan dengan PKWTT lebih tinggi daripada guru yang berstatus karyawan dengan PKWT (Gupta \& Gupta, 2013). Penelitian serupa juga dilakukan Moradi, dkk. (2014) mengemukakan karyawan dengan PKWTT memiliki kualitas kehidupan kerja yang lebih tinggi dibandingkan dengan karyawan dengan PKWT. Menurut Denvir, dkk. (2007) karyawan yang memiliki kualitas kehidupan kerja yang tinggi akan merasa seperti : memiliki kepercayaan terhadap atasan, saling menghormati, bekerja dengan jam kerja yang sesuai, mendaptkan gaji yang sesuai, ada kesempatan untuk promosi jabatan, serta mendapat perlaku yang adil.

Menurut Moradi, dkk. (2014) karyawan dengan PKWTT memiliki prospek karir yang baik serta pendapatan yang lebih tinggi dibandingkan dengan karyawan dengan PKWT. Adanya perbedaan imbalan antara karyawan dengan PKWTT dan karyawan dengan PKWT menyebabkan adanya perbedaan kualitas kehidupan kerja yang ditunjukkan oleh karyawan dengan PKWTT dan karyawan dengan PKWT. Hal ini disebabkan karena rewards and fairness merupakan dimensi dari kualitas kehidupan kerja yang dipaparkan oleh Denvir, dkk. (2007). Faktor lain yang menyebabkan adanya perbedaan kualitas kehidupan kerja antara karyawan dengan PKWTT dan karyawan dengan PKWT dikarenakan adanya ketidaksesuaian yang dialami oleh karyawan dengan PKWT yaitu dikontrak lebih dari tiga tahun, namun tidak angkat menjadi karyawan dengan PKWTT. Hal ini dapat dilihat dari kategorisasi subjek berdasarkan lama bekerja pada karyawan dengan PKWT terdapat enam karyawan yang memiliki jangka waktu lama bekerja empat hingga tujuh tahun, tiga karyawan dengan jangka waktu lama bekerja delapan sampai sepuluh tahun, dan tiga karyawan dengan jangka waktu bekerja lebih dari sepuluh tahun.

Berdasarkan Undang-Undang Ketenagakerjaan Nomor 13 Tahun 2003, menyebutkan bahwa perjanjian kerja waktu tertentu dapat diadakan untuk paling lama dua tahun dan hanya boleh diperpanjang satu kali untuk jangka waktu paling lama satu tahun. Masa kerja karyawan dengan PKWT ditetapkan oleh perusahaan, sehingga ketika kontrak kerjaberakhir, terdapat kemungkinan karyawan akan diangkat menjadi karyawan dengan PKWTT, masa kontrak karyawan akan diperpanjang, dan masa kontrak tidak perpanjang. Lain halnya pada karyawan dengan PKWTT, masa kerja antara karyawan dengan perusahaan tidak ditetapkan (Donsari \& Irawati, 2015). Adanya ketidakpastian jenjang karir yang dialami karyawan dengan PKWT dapat menyebabkan kualitas kehidupan kerja yang rendah. Hal ini didukung oleh penelitian yang dilakukan oleh Rose et al (2006) menunjukkan bahwa kepuasan karir, pencapaian karir, dan keseimbangan karir memiliki korelasi terhadap kualitas kehidupan kerja.

Berbanding terbalik dengan hasil penelitian ini yang menunjukkan bahwa karyawan dengan PKWT menunjukkan kualitas kehidupan yang tinggi. Menurut Noor dan Abdullah (2013) terdapat beberapa cara untuk meningkatkan kualitas kehidupan kerja karyawan yaitu dengan keaktifan organisasi yang mampu memelihara kepemimpinan, adanya program yang menanamkan rasa memiliki di antara karyawan serta adanya program pengembangan perusahaan dan karyawan untuk pertumbuhan dan pengembangan karyawan. Hal tersebut diduga sudah diterapkan pada perusahaan hotel di Bali, sehingga pada karyawan dengan PKWTT maupun karyawan dengan PKWT tidak terdapat kualitas kehidupan kerja yang rendah, namun tidak diteliti dalam penelitian ini.

Uji hipotesis minor ketiga yang bertujuan untuk mengetahui adanya hubungan fungsional antara kualitas kehidupan kerja dan perilaku kewargaan organisasi, secara lebih rinci dijelaskan melalui analisis regresi sederhana. Hubungan fungsional merupakan hubungan yang membedakan antara variabel bebas dan variabel terikat, yang mana variabel bebas memiliki pengaruh terhadap variabel terikat (Ghozali, 2012). Hasil analisis regresi sederhana menunjukkan terdapat nilai $\mathrm{R}$ yang merupakan koefisien regresi sebesar 0,802 dengan nilai adjusted $\mathrm{R}$ square yang merupakan nilai koefisien determinasi sebesar 0,641 yang memiliki arti bahwa variabel kualitas kehidupan kerja dapat menjelaskan variabel perilaku kewargaan organisasi sebesar 64,1\%. Nilai signifikansi 0,000 $(\mathrm{p}<0,05)$ menunjukkan bahwa ada hubungan fungsional antara kualitas kehidupan kerja dan perilaku kewargaan organisasi pada karyawan hotel di Bali.

Kualitas kehidupan kerja didefinisikan sebagai strategi tempat kerja yang mendukung dan memelihara kepuasan karyawan dengan tujuan untuk meningkatkan kondisi kerja karyawan dan organisasi serta keuntungan untuk pemberi kerja (Lau \& May, 1998). Karyawan yang puas dengan kualitas kehidupan kerja memiliki perilaku kewargaan yang lebih tinggi dalam organisasi (Nair, 2013). Semakin besar tingkat kualitas kehidupankerja maka semakin besar pula tingkat perilaku kewargaan organisasi yang dimiliki oleh karyawan (Aini, dkk., 2014).

Adanya hubungan fungsional antara kualitas kehidupan kerja 
dan perilaku organisasi sejalan dengan penelitian yang dilakukan Nair (2013) yang menunjukkan bahwa kualitas kehidupan kerja secara signifikan memengaruhi perilaku kewargaan organisasi. Hasil penelitian yang dilakukan oleh Aini, dkk. (2014) juga menemukan bahwa kualitas kehidupan kerja memiliki pengaruh yang signifikan terhadap perilaku kewargaan organisasi. Lingkungan organisasi yang positif, dapat menyebabkan karyawan merasa ingin melakukan pekerjaannya melebihi apa yang telah diharapkan dalam uraian pekerjaan, dan akan selalu mendukung tujuan organisasi jika diperlakukan oleh para atasan dengan sportif dan dengan penuh kesadaran serta percaya bahwa mereka diperlakukan secara adil oleh perusahaannya (Organ, dkk., 2006).

Berdasarkan seluruh pemaparan pada penelitian ini, dapat disimpulkan bahwa terdapat perbedaan perilaku kewargaan organisasi berdasarkan status kerja karyawan hotel di Bali ditinjau dari kualitas kehidupan kerja. Peningkatan taraf perilaku kewargaan organisasi setelah adanya kontrol pada kualitas kehidupan kerja, menunjukkan bahwa kualitas kehidupan kerja lebih berkontribusi dibandingkan dengan status kerja karyawan terhadap perilaku kewargaan organisasi. Hal ini diperkuat dengan hasil uji regresi sederhana yang menunjukkan bahwa kualitas kehidupan kerja berperan terhadap perilaku kewargaan organisasi. Terdapat perbedaan kualitas kehidpan kerja dan perilaku kewargaan organisasi antara karyawan dengan PKWTT dan karyawan dengan PKWT yang bekerja pada hotel di Bali. Karyawan dengan PKWTT menunjukkan rata-rata skor kualitas kehidupan kerja dan perilaku kewargaan organisasi yang lebih tinggi dibandingkan dengan karyawan dengan PKWT.

Adapun beberapa keterbatasan pada penelitian ini yaitu waktu pengambilan data yang memerlukan waktu yang cukup lama, yaitu selama satu setengah bulan. Hal ini dikarenakan adanya kesibukan pada masing-masing hotel tempat karyawan bekerja. Selain itu, setelah melakukan randomisasi terhadap hotel-hotel yang akan dijadikan sampel, ditemukan bahwa terdapat hotel yang hanya memiliki karyawan dengan status kerja yang sama. Keterbatasan lain dalam penelitian ini adalah tidak dilakukannya analisis tambahan berdasarkan data demografi subjek. Kurangnya menggali data demografi yang lebih lengkap, seperti berapa kali perpanjangan kontrak yang telah dilakukan karyawan PKWT. Jumlah aitem yang tercantum pada skala penelitian ini memungkinkan subjek merasa kelelahan ketika mengisi skala juga merupakan keterbatasan dalam penelitian ini.

Berdasarkan penelitian yang telah dilakukan, dapat ditarik kesimpulan yaitu ada perbedaan perilaku kewargaan organisasi berdasarkan status kerja karyawan hotel di Bali ditinjau dari kualitas kehidupan kerja. Kualitas kehidupan kerja memiliki kotribusi yang lebih besar daripada status kerja karyawan terhadap perilaku kewargaan organisasi.

Ada perbedaan perilaku kewargaan organisasi antara karyawan dengan PKWTT dan karyawan dengan PKWT pada hotel di Bali, karyawan dengan PKWTT memiliki skor perilaku kewargaan organisasi yang lebih tinggi dibandingkan dengan karyawan dengan PKWT. Karyawan yang memiliki perilaku kewargaan organisasi yang tinggi akan menunjukkan sikap seperti : suka meonolong karyawan lain, memiliki sikap sportif, tetap setia pada organisasi, bekerja dengan maksimal, memiliki inisiatif, aktif berpartisipasi terhadap organisasi, serta secara sukarela meningkatkan kemampuan yang dimiliki. Karyawan dengan PKWTT dan karyawan dengan PKWT memiliki perbedaan pula pada kualitas kehidupan kerja pada hotel di Bali, karyawan dengan PKWTT memiliki skor kualitas kehidupan kerja yang lebih tinggi dibandingkan karyawan dengan PKWT. Karyawan yang memiliki kualitas kehidupan kerja yang tinggi akan merasa seperti : memiliki kepercayaan terhadap atasan, saling menghormati, bekerja dengan jam kerja yang sesuai, mendaptkan gaji yang sesuai, ada kesempatan untuk promosi jabatan, serta mendapat perlaku yang adil. Serta ada hubungan fungsional antara kualitas kehidupan kerja dan perilaku kewargaan organisasi.

Berdasarkan kesimpulan yang telah dipaparkan, maka beberapa saran yang dapat diberikan yaitu bagi perusahaan, diharapkan dapat memberikan pelatihan serta pengembangan yang tepat pada karyawan guna meningkatkan dan mempertahankan kualitas kehidupan kerja serta perilaku kewargaan organisasi yang dimiliki oleh karyawan dengan PKWTT dan karyawan dengan PKWT. Selain itu, penting bagi perusahaan untuk mematuhi aturan yang sesuai dengan Undang-Undang Ketenagakerjaan Nomor 13 Tahun 2003, khususnya mengenai kontrak kerja karyawan dengan PKWT agar dapat meningkatkan kualitas kehidupan kerja dan perilaku kewargaan organisasi. Bagi karyawan, penelitian ini diharapkan dapat memberikan gambaran mengenai kualitas kehidupan kerja dan perilaku kewargaan organisasi, sehingga dapat meningkatkan kualitas diri sebagai karyawan khususnya pada aspek kualitas kehidupan kerja dan perilaku kewargaan organisasi agar memberikan dampak yang positif bagi diri sendiri dan perusahaan, baik karyawan dengan PKWTT maupun karyawan dengan PKWT.

Saran bagi peneliti selanjutnya yaitu peneliti selanjutnya sebaiknya mengantisipasi proses perizinan dan penyebaran data pada hotel-hotel di Bali membutuhkan waktu yanglama, dengan cara menyebarkan data ke lebih banyak hotel. Peneliti selanjutnya sebaiknya melakukan pengacakan aitem yang tidak mudah diprediksi oleh subjek saat menyusun alat ukur baik kualitas kehidupan kerja dan perilaku kewargaan organisasi. Jumlah aitem yang terlalu banyak dalam kuisioner dapat menimbulkan efek kelelahan pada subyek saat menjawab, maka dari itu peneliti selanjutnya dapat lebih mempertimbangkan jumlah aitem serta cara penyajian aitem. Peneliti selanjutnya sebaiknya menggali lebih dalam data demografi, seperti berapa kali perpanjangan kontrak yang telah dilakukan karyawan dengan PKWT agar dapat dilakukan uji analisis tambahan berdasarkan data demografi. Bagi peneliti selanjutnya sangat mungkin dilakukan replikasi. Peneliti selanjutnya dapat mengganti jenis variabel atapun mengganti subjek, tidak hanya menggolongkan berdasarkan status kerja karyawan namun melibatkan faktor-faktor lain dapat megungkap perilaku kewargaan organisasi, kualitas kehidupan kerja, maupun variabel lainnya, sehingga dapat memperoleh data penelitian yang beragam dan bermanfaat.

\section{DAFTAR PUSTAKA}




\section{N.W.S WIDIASTUTI \& K.R INDRAWATI}

Aini, F. A., Hardjajani, T., \& Priyatama, A. N. (2012). Hubungan antara kualitas interaksi atasan-bawahan dan quality of work life dengan organizational citizenship behavior karyawan PT. Air Mancur Palur Karanganyar. Jurnal Ilmiah Psikologi Candrajiwa, 1, 1-13.

Alkahtani, A. (2015). Organizational citizenship behavior (OCB) and rewards.

International Business Research , 8, 210-222.

Asgari, M. H., Taleghani, M., \& Abadikhah, S. (2012). The relationship between quality of working life with organizational citizenship behavior of office of education staff in Rasht City. Journal of Basic and Applied Scientific Research, 2, 3547-3551.

Badan Pusat Statistik (BPS). (2015). Jumlah akomodasi, kamar, dan tempat tidur yang tersedia pada hotel bintang menurut provinsi, 2000-2015. Dipetik Mei 2016, 1, dari Badan Pusat Statistik: https://www.bps.go.id

Badan Pusat Statistik (BPS). (2015). Jumlah kedatangan wisatawan per tahun ke Bali menurut pintu masuk, 2010-2015. Dipetik Mei 1, 2016, dari Badan Pusat Statistik: https://www.bps.go.id

Badan Pusat Statistik (BPS). (2016, Mei 2). Tingkat penghunian kamar pada hotel bintang menurut provinsi tahun 20082016 (persen). Dipetik Mei 15, 2016, dari Badan Pusat Statistik: https://www.bps.go.id

Chang, K., \& Chelladura, P. (2003). Comparison of part-time workers and full-time workers: Commitment and citizenship behaviors in Korean Sport Organizations. Human Kinetics Journals, 7, 394-416.

Denvir, A., Hillage, J., Cox, A., Sinclair, A., \& Pearmain, D. (2007). Quality of working life in the UK. Institute for Employment Studies, 1-65.

Donsari, Y. P., \& Irawati, R. (2015). Perbedaan kepuasan kerja karyawan dalam penerapan perjanjian kerja di PT. TPCO PAN ASIA cabang Batam. Jurnal Akutansi, Ekonomi dan Manajemen Bisnis , 3, 1-13.

Dyne, L. V., \& Ang, S. (1998). Organizational citizenship behavior of contingent workers in Singapore. The academy of management journal , 41 (6), 692-703.

Ellya. (2016, September 1). Di PHK, karyawan demo manajemen Novotel Semarang.

Dipetik Maret 19, 2017, dari Berita Jateng: http://beritajateng.net

Febriani, N. M., \& Indrawati, A. D. (2013). Pengaruh motivasi, kompensasi, serta lingkungan kerja fisik terhadap kinerja kerja karyawan hotel The Niche Bali. E- journal Management , 2 (5), 541-551.

Ghozali, I. (2012). Aplikasi analisis multivariate dengan program IMB SPSS 20.

Semarang: Badan Penerbit Universitas Diponegoro.

Gupta, P., \& Gupta, R. (2013). Comparative study between permanent and contractual teacher's quality of work life: A study in higher education. International Journal of Advanced Research in Management and Social Sciences, 2, 231-244.

Gurudatt, K., \& Gasal, Y. (2015). Role of (QWL) quality of work life on employee retention in private sector companies. International Journal of Engineering and Management Sciences, 6(1), 11-15.

Hartono. (2013, Oktober 24). Dilema karyawan outsourcing dan kontrak. Dipetik Maret 19, 2017, dari Direktorat Jendral Pajak Kementrian Keuangan: http://www.pajak.go.id

Hunker, I. K. (2014). Quality of work life in the hospitality industry. Copenhagen business school, 1-71.

International Labor Organization (ILO). (2015). Tren ketenagakerjaan dan sosial di Indonesia 2014 - 2015.
Dipetik Mei 25, 2016, dari International labour organization: http://www.ilo.org

Jati, A. N. (2013). Kualitas kehidupan kerja dan komitmen organisasional: Hubungannya dengan organization citizenship behavior. Kiat Bisnis, 5, 97-103.

Khanifar, H., Saeedi, S. R., \& Shojaee, S. (2013). Management citizenship behavior: Definitions, formation and the consequences in organization. Elixir International Journal, 57, 14149-14153.

Lau, R. S., \& May, B. E. (1998). A win-win paradigma for quality of work life and business performance. Human Resource Development Quarterly, 9(3), 256-272.

Ma, E. (2011, Januari 22). Social exchanges as motivators of hotel employees organizational citizenship behavior: the proposition and pplication of a new three dimensional framework. Dipetik Maret 29, 2017, dari Science Direct: http://www.sciencedirect.com

Moradi, T., Maghaminejad, F., \& Fini, I. A. (2014). Quality of working life of nurses and its related factors. Nurs Midwifery Study, 3(2), 1-6.

Nair, G. S. (2013). A study on the effect of quality of work life (QWL) on organizational citizenship behaviour - With spesial reference to collage teachers in Thirssur District, Kerala. Integral Review: A Journal of Management , 6 (1), $34-46$.

Ngugi, J. (2017). Role of working conditions on organization citizenship behaviour in the banking industry: A survey of Barclays Bank in North Rift Region. IOSR Journal of Business and Management , 19 (6), 32-37.

Noor, S. M., \& Abdullah, M. A. (2012). Quality work life among factory workers in Malaysia. Procedia Social and Behavioral Sciences, 35, 739-745.

Onyishi, I. E. (2010). The impact of contingent employment on organizational citizenship behaviour. An International Journal, 18(2), 303-323.

Organ, D. W., Podsakoff, P. M., \& MacKenzie, S. B. (2006). Organizational citizenship behavior: Its nature, antecedents, and consequences. California: Sage Publication.

Oskamp, S. (1984). Applied social psychology. Englewood Cliffs, New Jersey: Prentice- Hall, Inc.

Papi, A., \& Nuralizadeh, R. (2014). Investigating the relationship between the quality of work life and the emergence of organizational citizenship behavior among primary school teachers in Andimeshk. International journal on new trends in education and literature , 1 (4), 32-42.

Puspitawati, N. M. (2013). Kepuasan kerja dan komitmen organisasional : Pengaruhnya terhadap kualitas layanan Hotel Bali Hyatt Sanur. Dipetik Mei 25, 2016, dari Kumpulan thesis program Pasca Sarjana Universitas Udayana: http://www.pps.unud.ac.id

Putri, M. K. (2015, September 10). Perbedaan kualitas kehidupan kerja ditinjau dari status karyawan. Dipetik Maret 19, 2017, dari Perpustakaan Universitas Gunadarma: http://library.gunadarma.ac.id

Riggio, R. E. (2009). Introduction to industrial/ organizational psychology. New Jersey: Pearson Education.

Robbins, S. P., \& Jugde, T. A. (2015). Perilaku organisasi. Jakarta: Salemba Empat.

Rose, R. C., Beh, L., Uli, J., \& Idris, K. (2006). Quality of work life: Implication of career dimensions. Journal of Social Sciences , 2 (2), 61-67.

Saraji, G. N., \& Dargahi, H. (2006). Study of quality of work life. Iranian Journal Public Health, 35(4), 8-14.

Sarina. (2017, Februari 22). Di-PHK sepihak, 40 pekerja perusahaan MNC Sky Vision demo. Dipetik Maret 19, 2017, dari Informasi Aceh: https://www.goaceh.com 
Soni, H., \& Rawal, Y. S. (2014). Impact of quality of work life on employee satisfaction in Hotel Industry. IOSR Journal of Business and Management (IOSR-JBM), 16(3), 37- 44.

Triyono, A. (2015). Perlindungan hukum terhadap hak-hak pekerja harian lepas (Studi kasus di CV. Indojati Surakarta). Eprints UMS, 1-16.

Undang-Undang Republik Indonesia Nomor 13 Tahun 2003 tentang Ketenagakerjaan.

Widiastuti, N. W. (2016). Studi pendahuluan: Studi kasus kepuasan kerja pada pekerja harian pada hotel di Bali. Denpasar: Tidak dipublikasikan.

Widyastutie, A. (2010). Perbedaan tingkat organizational citizenship behavior pada karyawan tetap dan karyawan kontrak. UMS EDT-tb .

Yosua, F. (2011). Analisis penggunaan daily worker pada departemen food \& berverage di Hotel Aryaduta Semanggi. Perpustakaan Usahid.

Yusran, A. (2015, Desember 7). Memprihatinkan, upah tenaga kontrak di Makassar Hanya Rp 500 Ribu. Dipetik Maret 2017, 29, dari Liputan 6: http://regional.liputan6.com 
Tabel 1

Deskripsi data penelitian variabel perilaku kewargaan organisasi

\begin{tabular}{ccccccccc}
\hline Kelompok & N & $\begin{array}{c}\text { Mean } \\
\text { Teoretis }\end{array}$ & $\begin{array}{c}\text { Mean } \\
\text { Empiris }\end{array}$ & $\begin{array}{c}\text { Std. } \\
\text { Deviasi } \\
\text { Teoretis }\end{array}$ & $\begin{array}{c}\text { Std. } \\
\text { Deviasi } \\
\text { Empiris }\end{array}$ & $\begin{array}{c}\text { Sebaran } \\
\text { Teoretis }\end{array}$ & $\begin{array}{c}\text { Sebaran } \\
\text { Empiris }\end{array}$ & Nilai t \\
\hline $\begin{array}{c}\text { Karyawan } \\
\text { dengan }\end{array}$ & 64 & 125 & 169,84 & 25 & 15,205 & $50-200$ & $131-195$ & $\begin{array}{c}23,595 \\
(\mathrm{p}=0,000)\end{array}$ \\
$\begin{array}{c}\text { PKWTT } \\
\begin{array}{c}\text { Karyawan } \\
\text { dengan } \\
\text { PKWT }\end{array}\end{array}$ & 62 & 125 & 160,60 & 25 & 23,870 & $50-200$ & $140-194$ & 19,975 \\
$(\mathrm{p}=0,000)$
\end{tabular}

Tabel 2 
Deskripsi data penelitian variabel kualitas kehidupan kerja

\begin{tabular}{ccccccccc}
\hline Kelompok & $\mathbf{N}$ & $\begin{array}{c}\text { Mean } \\
\text { Teoretis }\end{array}$ & $\begin{array}{c}\text { Mean } \\
\text { Empiris }\end{array}$ & $\begin{array}{c}\text { Std. } \\
\text { Deviasi } \\
\text { Teoretis }\end{array}$ & $\begin{array}{c}\text { Std. } \\
\text { Deviasi } \\
\text { Empiris }\end{array}$ & $\begin{array}{c}\text { Sebaran } \\
\text { Teoretis }\end{array}$ & $\begin{array}{c}\text { Sebaran } \\
\text { Empiris }\end{array}$ & Nilait \\
\hline $\begin{array}{c}\text { Karyawan } \\
\text { dengan }\end{array}$ & 64 & 230 & 297,30 & 46 & 24,772 & $92-368$ & $261-358$ & $\begin{array}{c}21,733 \\
(\mathrm{p}=0,000)\end{array}$ \\
$\begin{array}{c}\text { PKWTT } \\
\text { Karyawan } \\
\begin{array}{c}\text { dengan } \\
\text { PKWT }\end{array}\end{array}$ & 62 & 230 & 288,53 & 46 & 23,870 & $92-368$ & $234-345$ & $\begin{array}{c}19,308 \\
(\mathrm{p}=0,000)\end{array}$ \\
\hline
\end{tabular}

Tabel 3

Hasil uji normalitas variabel penelitian 


\begin{tabular}{cccc}
\hline $\begin{array}{c}\text { One-Sample Kolmogorov-Smirnov } \\
\text { Test }\end{array}$ & $\begin{array}{c}\text { Kolmogorov- } \\
\text { Smirnov }\end{array}$ & $\begin{array}{c}\text { Asymp. Sig. } \\
\text { (2-tailed) }\end{array}$ & Keterangan \\
\hline Perilaku Kewargaan Organisasi & 1,047 & 0,223 & Data Normal \\
\hline Kualitas Kehidupan Kerja & 0,966 & 0,308 & Data Normal \\
\hline
\end{tabular}


Hasil uji homogenitas variabel penelitian

\begin{tabular}{cccc}
\hline $\begin{array}{c}\text { Levene Test for Equality of } \\
\text { Variance }\end{array}$ & Levene Statistic & Sig. & Keterangan \\
\hline Perilaku Kewargaan Organisasi & 0,591 & 0,443 & Data Homogen \\
\hline Kualitas Kehidupan Kerja & 1,190 & 0,277 & Data Homogen \\
\hline
\end{tabular}

Tabel 5 
Hasil uji linieritas variabel penelitian

\begin{tabular}{|c|c|c|c|c|}
\hline & & & $\mathbf{F}$ & Sig. \\
\hline Perilaku Kewargaan & Between & Linearity & 252,536 & 0,000 \\
\hline $\begin{array}{c}\text { Organisasi*Kualitas } \\
\text { KehidupanKerja }\end{array}$ & Group & Deviation from Linearity & 1,243 & $\overrightarrow{0,199}$ \\
\hline
\end{tabular}


Tabel 6

Hasil uji multikolinieritas variabel penelitian

\begin{tabular}{|c|c|c|c|c|c|c|c|c|}
\hline \multicolumn{9}{|c|}{ Coefficients $^{\mathrm{n}}$} \\
\hline \multirow[t]{2}{*}{ Mode } & & \multicolumn{2}{|c|}{$\begin{array}{c}\text { Unstandardized } \\
\text { Coefficients }\end{array}$} & \multirow{2}{*}{$\begin{array}{l}\text { Standardized } \\
\text { Coefficients } \\
\text { Beta }\end{array}$} & \multirow[t]{2}{*}{$\mathrm{T}$} & \multirow[t]{2}{*}{ Sig. } & \multicolumn{2}{|c|}{$\begin{array}{c}\text { Collinearity } \\
\text { Statistics }\end{array}$} \\
\hline & & B & Std. Error & & & & Tolerance & VIF \\
\hline \multirow{2}{*}{1} & (Constant) & 19,259 & 9,791 & & 1,967 &, 051 & & \\
\hline & KKK & 498 & .033 & 802 & 14,968 & .000 & 1,000 & 1,000 \\
\hline
\end{tabular}

a. Dependent Variable: PKO 
Tabel 7

Hasil uji hipotesis mayor (adanya kontrol terhadap kovariat)

Dependent Variable: Perilaku Kewargaan Organisasi

\begin{tabular}{lccccc}
\hline \multicolumn{1}{c}{ Source } & $\begin{array}{c}\text { Type III Sum of } \\
\text { Squares }\end{array}$ & Df & Mean Square & F & Sig. \\
\hline Corrected Model & $19614,434^{\mathrm{a}}$ & 2 & 9807,217 & 124,956 & 0,000 \\
\hline Intercept & 514,011 & 1 & 514,011 & 6,549 & 0,012 \\
\hline $\begin{array}{l}\text { Kualitas } \\
\text { Kehidupan Kerja }\end{array}$ & 16921,656 & 1 & 16921,656 & & 0,000 \\
\hline Status Kerja & 774,154 & 1 & 774,154 & 215,603 & 0,002 \\
\hline Error & 9653,701 & 123 & 78,485 & 9,864 & \\
\hline Total & 3471839,000 & 126 & & & \\
\hline Corrected Total & 29268,135 & 125 & & & \\
\hline a. R Squared $=670$ (Adjusted $R$ Squared $=, 665)$ & & &
\end{tabular}


Tabel 8

Hasil Uji Hipotesis Mayor (tanpa adanya kontrol terhadap kovariat)

Dependent Variable: Perilaku Kewargaan Organisasi

\begin{tabular}{lccccc}
\hline \multicolumn{1}{c}{ Source } & $\begin{array}{c}\text { Type III Sum of } \\
\text { Squares }\end{array}$ & Df & Mean Square & F & Sig. \\
\hline $\begin{array}{l}\text { Corrected } \\
\text { Model }\end{array}$ & $2692,778^{\mathrm{a}}$ & 1 & 2692,778 & 12,564 & 0,001 \\
\hline Intercept & 3438648,016 & 1 & 3438648,016 & 16044,652 & 0,000 \\
\hline Status Kerja & 2692,778 & 1 & 2692,778 & 12,564 & 0,001 \\
\hline Error & 26575,357 & 124 & 214,317 & & \\
\hline Total & 3471839,000 & 126 & & & \\
\hline Corrected Total & 29268,135 & 125 & & & \\
\hline a. R Squared $=092$ (Adjusted $R$ Squared $=, 085)$ & & & & \\
\hline
\end{tabular}


Tabel 9

Hasil uji independent sample t-test

\begin{tabular}{ccccc}
\hline Independent Sample T-Test & F & T & Sig. (2-Tailed) & Keterangan \\
\hline Perilaku Kewargaan Organisasi & 0,591 & 3,545 & 0,001 & $\begin{array}{c}\text { Ho ditolak } \\
\text { Ha diterima }\end{array}$ \\
\hline Kualitas Kehidupan Kerja & 1,190 & 2,021 & 0.045 & $\begin{array}{c}\text { Ho ditolak } \\
\text { Ha diterima }\end{array}$ \\
\hline
\end{tabular}


PERILAKU KEWARGAAN ORGANISASI BERDASARKAN STATUS KERJA KARYAWAN

Tabel 10

Hasil uji regresi nilai r squared

\begin{tabular}{cccc}
\hline $\mathbf{R}$ & $\mathbf{R}$ Square & Adjusted $\mathbf{R}$ Square & Std. Error of the Estimate \\
\hline 0,802 & 0,644 & 0,641 & 9,170 \\
\hline
\end{tabular}


Tabel 11

Hasil uji regresi signifikansi nilai $\mathrm{F}$

\begin{tabular}{lccccl}
\hline & Sum of Squares & df & Mean Square & F & Sig. \\
\hline Regression & 18840,280 & 1 & 18840,280 & 224,034 & $.000^{\mathrm{b}}$ \\
Residual & 10427,855 & 124 & 84,096 & & \\
\hline Total & 29268,135 & 125 & & & \\
\hline
\end{tabular}

a. Dependent Variable: Perilaku Kewargaan Organisasi

b. Predictors: (Constant), Kualitas Kehidupan Kerja 
Tabel 12

Hasil uji regresi nilai koefisien beta dan nilai $\mathrm{T}$

\begin{tabular}{cccccc}
\hline Model & \multicolumn{2}{c}{ Unstandardized Coefficients } & $\begin{array}{c}\text { Standardized } \\
\text { Coefficients }\end{array}$ & t & Sig. \\
\cline { 3 - 5 } & B & Std. Error & Beta & & \\
\hline (Constant) & 19,259 & 9,791 & & 1,967 & 14,968 \\
\hline Kualitas Kehidupan Kerja & 0,498 & 0,033 & 0,802 & 14,968 & 0,000 \\
\hline a. Dependent Variable: Perilaku Kewargaan Organisasi & & &
\end{tabular}

a. Dependent Variable: Perilaku Kewargaan Organisasi 
Tabel 13

Rangkuman hasil uji hipotesis penelitian

\section{Hipotesis}

Hasil

\begin{tabular}{|c|c|}
\hline $\begin{array}{l}\text { Hipotesis Mayor } \\
\text { 1. Ada perbedaan perilaku kewargaan organisasi berdasarkan status kerja } \\
\text { karyawan hotel di Bali ditinjau dari kualitas kehidupan kerja. }\end{array}$ & Ha diterima \\
\hline \multicolumn{2}{|l|}{ Hipotesis Minor } \\
\hline $\begin{array}{l}\text { 1. Ada perbedaan perilaku kewargaan organisasi antara karyawan dengan } \\
\text { PKWTT dan karyawan dengan PKWT pada hotel di Bali. }\end{array}$ & Ha diterima \\
\hline $\begin{array}{l}\text { 2. Ada perbedaan kualitas kehidupan kerja antara karyawan dengan PKWTT } \\
\text { dan karyawan dengan PKWT pada hotel di Bali. }\end{array}$ & Ha diterima \\
\hline $\begin{array}{l}\text { 3. Ada hubungan fungsional antara kualitas kehidupan kerja dan perilaku } \\
\text { kewargaan organisasi. }\end{array}$ & Ha diterima \\
\hline
\end{tabular}

